\title{
THE SOUTH BASILICA AT ARSINOE (POLIS-TES-CHRYSOCHOU) Change and Innovation in an Early Christian Basilica on Cyprus
}

\author{
William CARAHER, R. Scott MOORE, \\ Brandon R. OLSON, Amy PAPALEXANDROU
}

\begin{abstract}
Résumé. La basilique Sud de Polis-tes-Chrysochou (ancienne Arsinoé), construite à la fin $d u v I^{e}$ siècle apr. J.-C., est une église chypriote typique de la fin de l'Antiquité. Nous discutons ici les modalités des transformations apportées à sa structure et la façon dont ses constructeurs ont résolu les problèmes que présentait ce site, en particulier en ce qui concernait l'eau et son drainage. Nous présentons ici pour la première fois la chronologie $d u$ bâtiment à partir des témoignages archéologiques en contexte et non d'une analyse stylistique de sa structure et de ses éléments décoratifs. Nous indiquons brièvement quelques relations possibles avec d'autres édifices de l'île et de la région.
\end{abstract}

Late antique Cyprus was a place of tremendous resources, wealth, and productivity. One measure of this is the large number of churches (no less than sixty-five) built between the $5^{\text {th }}$ and $7^{\text {th }}$ centuries AD. Nearly all these buildings were basilicas, many of them large and deluxe in decoration and furnishing. As prominent visual indicators of the Church and its power, they accommodated the growing religious needs of local populations while advertising the prestige of both the ecclesiastical hierarchy and the Christianised, secular elite in virtually every city and town on the island. Within this increasingly Christianised landscape, the untamed area of north-western Cyprus stood somewhat apart, as it still does today. The main town of the region, now known as Polis tes Chrysochou, occupies the site of ancient Marion, re-founded as Arsinoe in the $3^{\text {rd }}$ century BC and known by this name for at least a millennium. The abundant late antique remains of Arsinoe suggest a community perhaps not as wealthy as Salamis or Paphos but equally vibrant and active in its building projects. Several important structures from the site dating to this period were excavated by a team from Princeton University between 1984 and 2005 and are now under study by the authors. In this paper we focus on one of two excavated churches, the South Basilica, discovered in 1984 in an area designated as E.F2 on the architect's grid. The goal of this short article is to provide some technical details and new analysis of the results of these earlier excavations. We discuss the original form and subsequent changes 
made to the South Basilica, the chronology of later alterations to its overall plan, and some of the problems encountered by builders during construction at what seems to have been a challenging site. We suggest some possible connections to other buildings in the region, especially where interaction and trade routes are suggested through archaeological discoveries.

Since 1983 the Princeton University team has conducted major excavation campaigns in five separate areas near the modern town of Polis. These have revealed significant remains of structures ranging in date from the early $7^{\text {th }}$ century $\mathrm{BC}$ through the $16^{\text {th }}$ century AD. ${ }^{1}$ Of these sites, three have yielded substantial late antique remains, all in close proximity to each other along the main road leading north from the town toward the Chrysochou Bay. In addition to the South Basilica another large, three-aisled basilica (the North Basilica, in area E.G0) was situated on a bluff overlooking the sea. ${ }^{2}$ A much smaller establishment, either domestic or industrial, was discovered between the two churches. The latter has not yet been studied and its function remains unclear. ${ }^{3}$

The South Basilica was a major focus of attention during the Princeton team's first season of excavation in 1984, when the east end of the church was discovered. Further campaigns in 1985-1986 and 1988-1990 saw the clearing of most of the building. Although it survives mainly at the level of the foundations, its floor plan is clear: it is a typical, medium-sized ( $18 \times 12.7 \mathrm{~m}$ nave and side aisles; $23.3 \times 16.6 \mathrm{~m}$ with narthex and south portico), three-aisled basilica with a central aisle flanked by two side aisles. A large section of the north aisle was robbed out before excavations were begun. In its first phase the aisles were separated from each other by columns or piers which supported clerestory walls and wooden roofs overhead. It is impossible to know whether these supports stood on an elevated stylobate or directly on the floor. The central aisle terminated in a polygonal (five-sided) apse, whereas the side apses were semi-circular. The narthex, the northern third of which remains unexcavated, was added to the building in a later campaign, as was a south portico that ran the entire length of the south aisle. These will be discussed below. Fragments of stone transennae and perhaps a chancel barrier testify to a programme of sculptural decoration, and an abundance of stone and glass tesserae, many with gold-leaf, were found near the east end suggesting the church was outfitted with a sophisticated programme of imagery. ${ }^{4}$ Traces of painted plaster and marble revetment also appeared in various fill levels linked to later phases of the church. Clearly the South Basilica was an important and visually impressive monument within this corner of the late antique town.

What follows is part of a larger study that focuses not only on the basilica itself but also on the larger area of E.F2. This encompassed a vibrant, multi-use neighbourhood in

1. Childs, Smith, Padgett 2012.

2. Najbjerg, Nicklies, Papalexandrou 2002.

3. Papalexandrou, Caraher 2012, p. 273-274.

4. Papalexandrou, Caraher 2012, p. 271. 
existence from at least as early as the Hellenistic period and functioning, in some form, throughout late antiquity and into the Middle Ages. The area seems to have supported dwellings together with a variety of industrial activities as suggested by evidence of smelting as well as a dense network of streets and waterworks. It is perhaps best demonstrated by the area below and east of the basilica, where a kiln produced terra cotta lamps from the $1^{\text {st }}$ century AD. ${ }^{5}$ The Late Roman period saw a substantial reorganisation of space in the area, with the construction of an apsidal well-house as well as the basilica under discussion here. These two structures largely respected the existing street plan, and the basilica was conceptualised as a key feature in the monumental landscape of the community.

While we will not elaborate on the later history of the church in any depth here, the basilica ultimately became the site for numerous burials (more than 250 individuals) perhaps as early as the late $7^{\text {th }}$ century and certainly in the centuries which followed. ${ }^{6}$ The ceramic evidence demonstrates that the church itself continued to stand in some form until at least the $11^{\text {th }}$ century. These later transformations will be part of a future study in which we will document this part of the site through time. In the present paper we address the first century or so of the basilica's life cycle, when it stood as a representative example of larger trends in architecture across the island and the region.

\section{Architectural Change in Late Antiquity}

Like so many sites on Cyprus, we have only the most fleeting evidence for any activity at the site of area E.F2, or Arsinoe in general, datable to the later $3^{\text {rd }}$ or $4^{\text {th }}$ centuries AD. It appears from ceramic evidence that several rooms to the southeast of the basilica (Fig. 1) probably stood from as early as the $1^{\text {st }}$ century $\mathrm{AD}$, with some modifications as late as the mid- $5^{\text {th }}$ century with its walls having collapsed prior to or shortly after the construction of the basilica in the $6^{\text {th }}$ century AD. The orientation of the church parallel to a paved road that runs along the south side of the excavated area, and perpendicular to a north-south road to the west, suggests that these thoroughfares continued to exist and be used during the lifetime of a basilica. The persistence of these roads may support the idea that the Roman-period monumental arch at the southwest of the site, through which the roads passed and intersected, continued to stand when the basilica was erected (Fig. 1). A series of long, east-west oriented rooms stood to the east of the south aisle, but the evidence for dating these structures here and elsewhere in the area remains fragmentary due to the digging of graves which disturbed the stratigraphy.

\section{First Phase of the Basilica}

The South Basilica initially comprised only the central nave and two side aisles (Fig. 2). The apses did not bond with the main walls of the church, a common convention in the early basilicas of Cyprus. There is little evidence for the superstructure aside from

5. Najbjerg 2012, p. 245.

6. Papalexandrou 2012, p. 29-35; Baker, Papalexandrou 2012. 


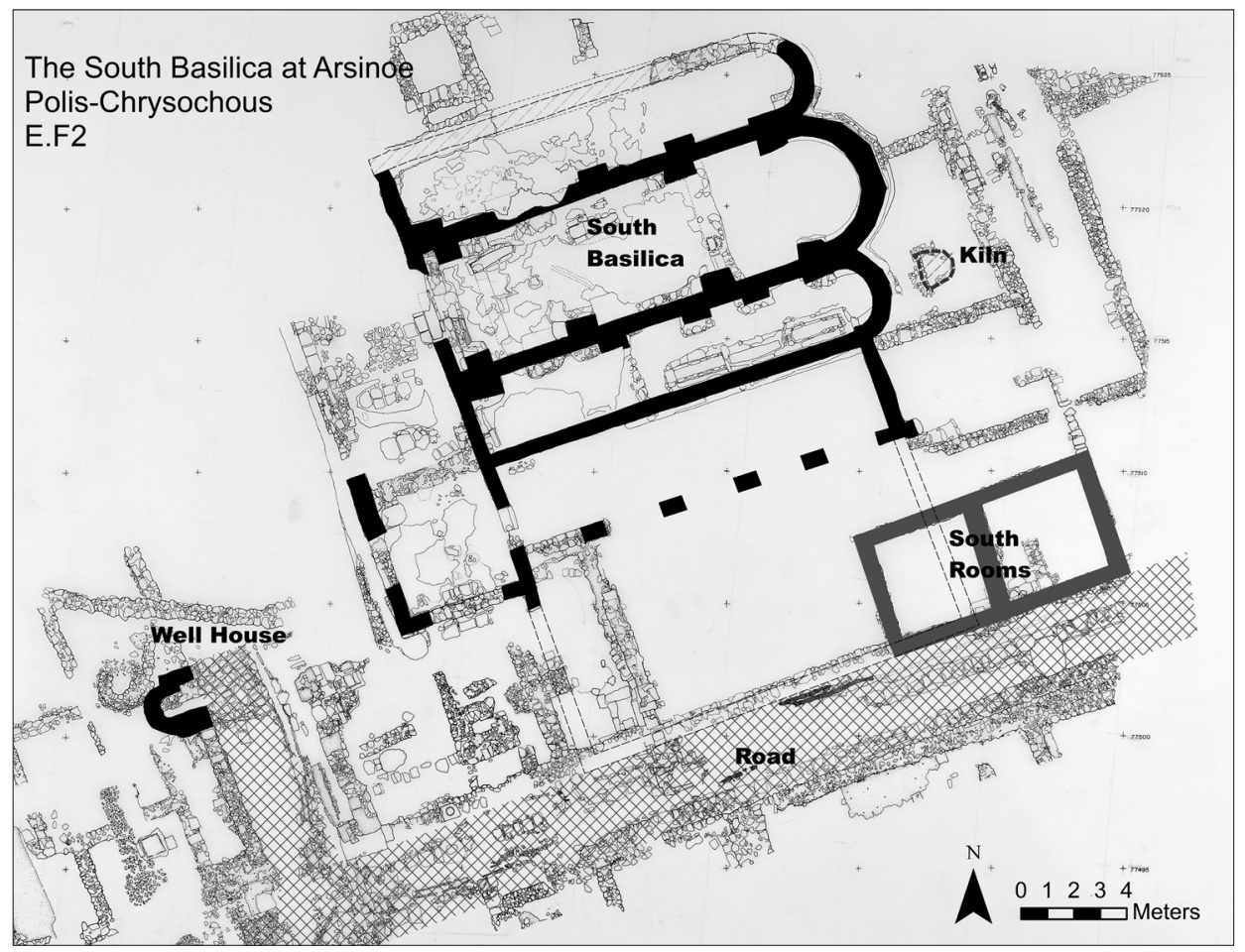

Figure 1. Area E.F2, Polis tes Chrysochou

(additions to the master plan: Princeton Cyprus Expedition Archive).

sections of fallen masonry discovered in the earliest excavation seasons, traces of a support for a chancel screen, and portions of piers that have survived above the level of the foundation. With so little surviving, we can say little about the structural support of the main nave in this phase. The date for the construction of the basilica remains obscure; its remodelling sometime in the middle of the $7^{\text {th }}$ century seemingly disturbed many of the construction fills associated with the original building. There are, however, a few hints. Excavations in 1990 followed the foundation trenches associated with the eastern apses, but these did not provide particularly diagnostic pottery. Excavations below the south nave and south aisle wall in the south aisle revealed Late Roman levels that contained Cypriot Red Slip (CRS) Form 9B, Form 11 and Form 2, which generally date to the second half of the $6^{\text {th }}$ century. This is more or less consistent with the lowest levels south of the church, which may be associated with a pre-basilica levelling of the area. Beneath a dense course of rubble which relates to the second phase of the basilica, there are Late Roman levels with CRS Form 8, Form 9 and imported Phocaean Ware Form 3. The latest coins in this level date to the late $4^{\text {th }}$ to $5^{\text {th }}$ centuries AD. None of this material produces a precise date for the construction of the basilica but, as we will argue below, its reconstruction in the 
$7^{\text {th }}$ century provides a terminus ante quem, and no material in any context earlier than the reconstruction of the church recommends a date later than the mid- to late $5^{\text {th }}$ century.

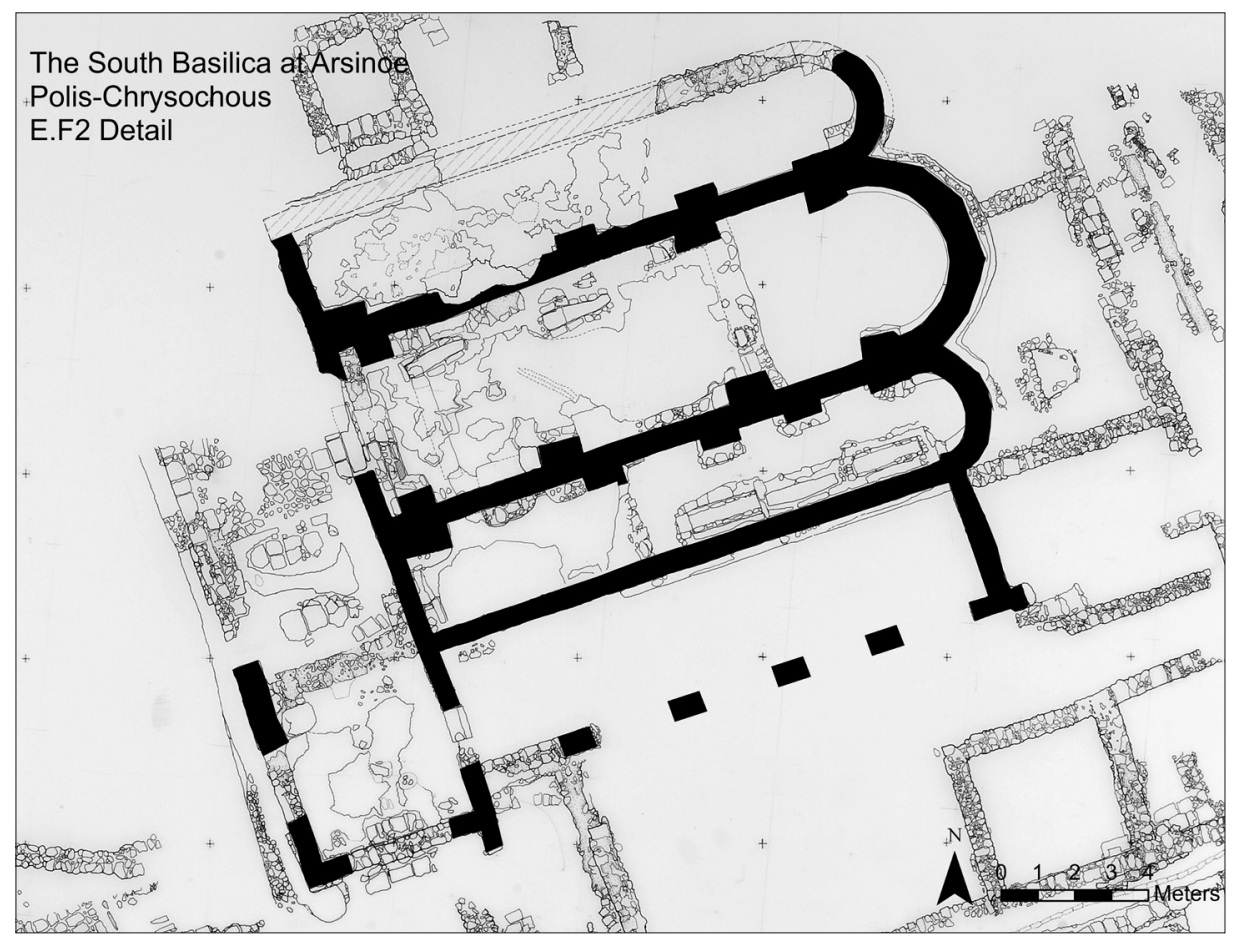

Figure 2. South Basilica, area E.F2, Polis tes Chrysochou

(Princeton Cyprus Expedition Archive).

The second phase of the church involved a complete reconstruction of the nave and the addition of a western narthex and spacious portico that ran the entire length of the south aisle (Fig. 2). The central nave received structural reinforcement at this time in the form of five buttresses placed at slightly irregular intervals along its north and south walls. These correspond, on occasion, to piers added to the aisle sides of these walls. The piers do not appear to bond with the nave foundations, and they most likely supported a barrel-vaulted roof overhead, at least in the central aisle. It is interesting that the two side aisles did not receive similar buttresses along their external walls, despite the fact that the wall thicknesses there are not substantial $(60 \mathrm{~cm})$. It is possible that the central vault was significantly higher than the side aisle vaults, or that the subsidiary aisles retained their wooden roofs. Discrepancies between the height of the central and side aisles is not uncommon in the churches of Cyprus; perhaps the best-known example is the Panayia Kanakaria at Lythrankomi, where the north aisle displays a similarly thin north wall, with 
corbels at the springing points rather than floor-level buttresses acting as supports. ${ }^{7}$ It is important to emphasise that this alteration to the structural system of the South Basilica at Polis occurred sometime before the middle of the $7^{\text {th }}$ century.

The narthex added to the building at this time extended across the west façade of the church and projected some five meters further to the south as an additional, spacious room or annex. This additional space was square in shape and projected slightly beyond the portico to the east, with which it communicated by means of a large, perhaps arched opening in a shared eastern wall. Neither the narthex nor the south portico bonded with the walls of the church, indicating their construction separate from the main body of the basilica.

The narthex was originally conceived as an open porch with its north, south, and west façades articulated by a series of large arched openings. These arches were aligned with the entrances into the central and south aisle, the south portico, and presumably the north aisle. The piers of the narthex arches had deep rubble foundations, and the spaces between them contained more shallow rubble foundations suggesting the presence of a low stylobate between the arches or the eventual closing of the arches. Excavations immediately west of the narthex did not reveal a proper foundation trench, but they did extend below the foundations of the southwest pier of the narthex. This trench produced no pottery later than the Late Roman period and included two examples of the $7^{\text {th }}$-century "well form" type of CRS associated with an important well deposit at Anemurium, as well as CRS 9 and a Late Roman 1 amphora in a relatively small assemblage. The "well form" pottery (Fig. $3 b$ ) provides a terminus post quem of the first third of the $7^{\text {th }}$ century for the narthex, and two examples have clear similarities to $7^{\text {th }}$-century forms from Anemurium and, on Cyprus, at Dhiorios. ${ }^{8}$

The earliest phase of the narthex seems to have featured a thin plaster floor. The levels beneath this floor, however, produced no diagnostic Late Roman pottery. A deeper sounding excavated in 1990 showed that the narthex stood directly on top of a relatively unmolested Hellenistic to Roman level. Additional walls, including the walling or partial filling-in of the arched openings with parapet walls, and a cobble surface dating to the medieval period indicate that the narthex underwent some significant modification over its lifespan. An almost complete Saraçhane Type 54B amphora, smashed by the collapse of a wall and sitting on top of a medieval surface, provides an indicator for the demise of this space. ${ }^{9}$

The south portico provides a terminus ante quem for the narthex. This space was wider than the south aisle and must have offered a protected and pleasant means of communication between the narthex and the open courtyard to the south. Its south façade consisted of a series of five arches that rested on columns or piers which were in turn

7. Megaw 1977.

8. Catling 1972; Williams 1977; Rautman 2003; Meyza 2007.

9. Hayes 1992. 
supported on four large pier foundations. The eastern and western-most arches ended in responds extending out from the east and west walls. It is possible that the portico, probably covered by a wooden shed roof that leaned against the south aisle, helped to counteract the lateral thrust exerted by the vaults and roof of the church. Since the east and south walls of the narthex bond, the portico must post-date the construction of the narthex or is at least contemporary with it. The similarities in architecture and construction technique - particularly the shape of the rubble foundations of the piers - indicate that the south portico and the narthex are close contemporaries. The large opening between them further supports this. Like the narthex, then, the south portico must post-date the nave, aisles, and eastern apses of the basilica.

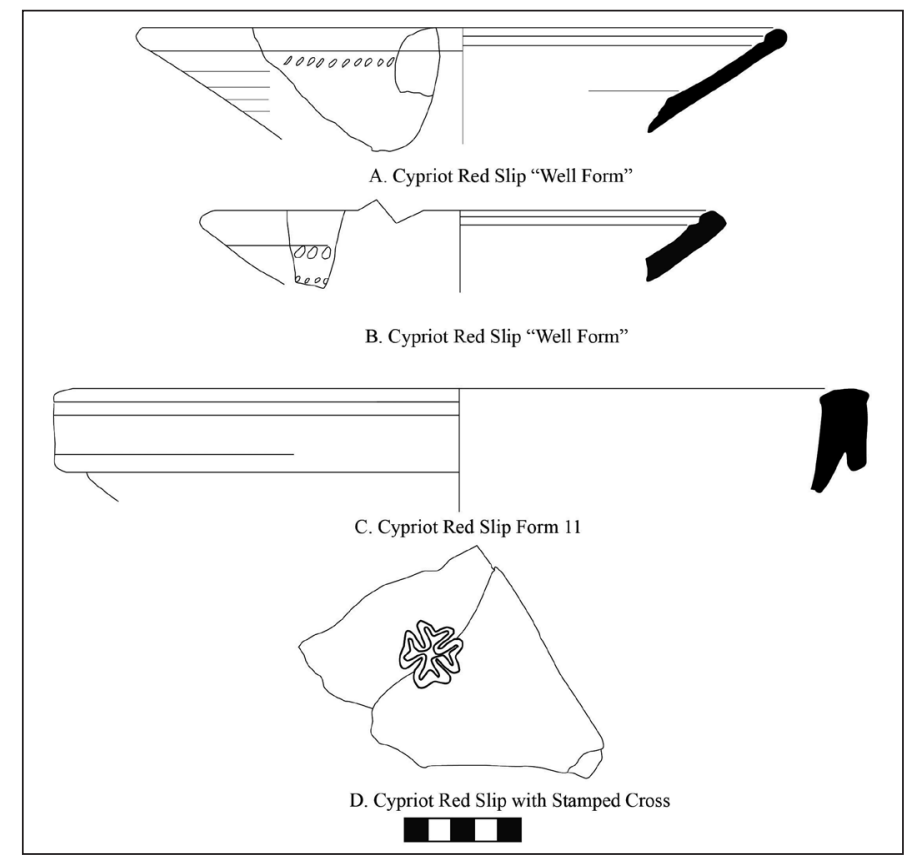

Figure 3. Ceramic Profiles, Polis-tes-Chrysochou (Brandon R. Olson).

At the western end of the south portico adjacent to the narthex, excavations exposed a well-preserved area of gypsum or re-crystallised limestone floor. Unfortunately, excavations beneath this floor revealed no diagnostic pottery except in a possibly contaminated level adjacent to but not directly below the underlying fill. Interestingly, an example of African Red Slip Form 105 appeared immediately above this floor. While the context for this artefact did not contain any material later than the sherd, it is impossible to determine whether this is a level associated with use or not.

The pier foundations of the portico seem to be cut into a massive rubble level that is more than a meter deep and extends north from the foundation of the south aisle. The use of the south portico for burials which were difficult to distinguish from the levels 
into which they were cut obscured the stratigraphy in the area. Moreover, the excavators struggled to identify foundation cuts in the rubble level that might provide datable deposits associated with the piers of the south portico. What is clear, however, is that the rubble level both surrounds the foundations of the piers and runs under them. Since this level could not both run under the piers and post-date them, it provides a terminus post quem for the piers. Coins of Maurice (582-602) in the rubble levels support a $7^{\text {th }}$-century date for the construction of the south portico and the narthex. Moreover, the area produced a consistent assemblage of Late Roman pottery with a robust collection of CRS Forms 1, 2, 7, 8, 9, 10 and 11, with the latest being probably CRS "well forms" which are almost identical to those found in the trench west of the narthex. It is notable that CRS "well forms" only appear in the trench to the west of the narthex and the large rubble level under the south portico.

The remains of a wall extending south from the portico leans against the portico but does not bond with it. This wall sits amidst a rubble level that appears to be architectural collapse and perhaps is related to the rubble fill across most of the area south of the basilica. As elsewhere, no foundation cuts were identified, meaning that this wall must be contemporary or earlier than the substantial Late Roman level that covers the two rooms to the southeast of the basilica, to which this wall belongs. The absence of any medieval material present in this fill and the preponderance of CRS make a Late Roman date for this wall likely. The wall was eventually cut by the tombs, perhaps during the medieval period. The date for this wall supports the $7^{\text {th }}$-century date for the portico.

Simultaneous with the construction of the narthex and south portico, the nave of the basilica underwent a substantial structural transformation. A series of buttresses and wallthickenings occurred along the north and south sides of the nave walls. These most likely supported a barrel-vaulted roof overhead. It is important that two joining fragments of the base of a CRS bowl with a stamped cross decoration (Fig. 3d) connect the rubble level south of the basilica with a foundation cut associated with a buttress along the north wall of the central aisle. This cut penetrated at least two levels of Late Roman fill in this area and into earlier Hellenistic and Roman levels that must pre-date the basilica. Sherds of CRS Form 9, Form 8 and Form 11, and Late Roman amphorae in the foundation cut associated with this buttress date this foundation cut to the same period as the south portico and the narthex, that is, the middle of the $7^{\text {th }}$ century.

Excavation around buttresses elsewhere in the central aisle confirms the date of the buttress along the north wall. In the central aisle, for example, excavators did not identify foundation cuts for the easternmost buttresses here, suggesting that these buttresses predate the fill in the apse. The excavation of the fills associated with the apse produced no pottery later than the Late Roman period and supports a terminus post quem for the construction of the buttresses to the $7^{\text {th }}$ century.

Excavations in the north aisle follow the dates of the buttresses elsewhere in the church. The fills associated with the lowest courses of the easternmost buttress on the north side of the north wall revealed an irregular, inverted stratigraphy preserving the practice of backfilling the fill in the opposite order that it was removed. The upper levels of the fill 
included Hellenistic to Roman pottery and the deeper levels produced a few CRS sherds including a Form 11 dating to no earlier than the second half of the $6^{\text {th }}$ century. Like the buttresses elsewhere in the church, the latest sherds are convincingly $6^{\text {th }}-7^{\text {th }}$ century and later material is entirely absent. The buttresses almost certainly date to less than a century after the initial construction of the church.

The dates of the wall thickening are somewhat less clear, but appear to be later than the buttresses. The episodes of wall-thickening tend not to rest on deep foundations or extend below the level of any one of the several floors present in the central or south aisle. At least one section of wall-thickening appears to be medieval, as it sits atop a floor associated with the latest levels of the basilica. In other places, the thickened wall appears to sit on Late Roman fills. In either case, a terminus post quem for the buttresses seems to be the rule and the rather insubstantial construction of the wall-thickening suggests that they were not weight bearing. This phenomenon was common in Cyprus, and previous efforts to date this modification to churches on the island have not been particularly compelling nor have they relied on datable stratigraphic deposits. ${ }^{10}$ The excavation of the buttresses at the E.F2 basilica dates the transformation of the wood-roofed basilica to a barrel-vaulted basilica to the 7th century at our site.

\section{Ceramics in Fill Levels}

The substantial fill assemblage associated with the second phase of the basilica presented an opportunity to study a large body of Late Roman pottery in a secondary context. The material all dates to no earlier than the middle years of the $7^{\text {th }}$ century and coincides nicely with the production cycles of most characteristic Late Roman pottery in the Eastern Mediterranean. This begins in the late $4^{\text {th }}$ century and tends to reach its final form by the early $7^{\text {th }}$ century. The fill produced substantial quantities of ceramics and the excavators preserved a large assemblage of diagnostic material. Nearly $80 \%$ of the material from the fill dated to the Roman period and $42.5 \%$ dates to the Late Roman period.

The Late Roman assemblage is diverse. It includes Late Roman 1 amphora, Palestinian amphora, Late Roman 7, and other less diagnostic amphora shapes. At least some of the Late Roman 1 amphorae were probably produced on the island and date to the 6th century. There were also a range of cooking ware shapes including so-called "frying pans" characteristic of Late Roman assemblages in Anatolia and the western part of Cyprus. There were a number of forms at Polis that were consistent with the Dhiorios assemblage with coarse, friable red and grey fabric and drooping rims. ${ }^{11}$ Various wares in coarse and medium coarse fabrics - such as basins and combed storage vessels - rounded out the more utilitarian component of the assemblage.

The most substantial group of material in the fill, however, were finewares, which accounted for close to $40 \%$ of the total assemblage of Late Roman material. CRS wares

10. Curčić 1999; Stewart 2010.

11. Catling 1972. 
comprise $97 \%$ of the fineware from the assemblage, and the distribution of different forms conforms rather closely to assemblages of CRS found elsewhere on the island. The most common form is the long-lived Form 9 which appeared in a wide range of shapes, most of which also occur at nearby Paphos. ${ }^{12}$ The presence of Form 1, which is the earliest form of CRS with examples dating to the $4^{\text {th }}$ century, and Form 2, which falls out of production by the middle of the $5^{\text {th }}$ century, speaks to the diachronic nature of our assemblage at Polis.

The only exception to the common distribution of CRS forms across the island is the greater percentage of Forms 7,8 and 11 which are present in our fill levels more than elsewhere in the region and on the island. The Form 11 ceramics present in our assemblage (Fig. 3c) tend to feature large folded rims with a distinct groove on the outside of the vessel where the rim folds over the body. This is similar to number 206 from Anemurium but less square, and there are few examples of this form from elsewhere on Cyprus. ${ }^{13}$ Forms 7 and 8 tend to feature flat rims with multiple grooves and do not show the range of related shapes present elsewhere on the island. The substantial presence of these larger forms of CRS may hint at the presence of a production site near the furthest western city on the island. It may also speak to the rather late date of activity at our site, as CRS11 and CRS8 represent two of the latest forms of this ware. The fill from the rooms southeast of the basilica also produced several sherds of "well form" CRS (Fig. 3a, b) which were produced as late as the first half of the $7^{\text {th }}$ century, confirming the rather late date of the fill and the activities that its residual pottery represented.

\section{Managing Water in Late Antique Arsinoe}

From as early as the Hellenistic period there is evidence for concerns about water management in the area around the South Basilica. There were numerous wells and drains associated with the workshops to the south and west of the basilica in the Hellenistic period. The Roman period saw the construction of complex systems of water pipes that ran along the paved roads and also crisscrossed the industrial installations present throughout the area. While these features likely contributed to the water supply for various industrial and domestic activities in the city of Polis, it is possible that they also served the important role of water management in the smaller area of E.F2. Its location on the slope of a hill and perpendicular to the course of a natural ravine likely exposed the site to the risk of seasonal flooding, especially in the event of torrential Mediterranean winter rains.

Several unusual features of the basilica appear to have been intended to protect the foundations from the flow of water south to north across the site. Various places along the exterior of the building preserved deposits of moist green clay seemingly placed along the foundation walls. In other places of area E.F2 a similar clay was associated with roof fall. Green clay was also found in abundance in the south portico, here also as part of roof fall. The waterproof character of this clay is recognised at the local level and has led to its continued use to seal roofs in Cyprus even until relatively recent times.

12. Meyza 2007.

13. Williams 1992. 
That the builders of the South Basilica had waterproofing concerns in mind is especially clear at the east end of the church. Several plaster layers were discovered in a 1990 sondage along the east face of the central apse wall where they were best preserved. These ran some $25 \mathrm{~cm}$ down the wall face and extended $20 \mathrm{~cm}$ out from the wall. Beneath it was a layer of green clay. This apparently represented an initial effort to prevent water from running down and penetrating into the softer soil of the foundation cut. The builders subsequently upgraded this initial attempt with a more well-defined plaster lip, or rim, which ran along the top of the roughly mortared foundation courses of the entire central apse and half of the two side apses. Like the waterproof clay and rough plaster application, the purpose of this additional rim was similarly to prevent water from running along the foundation through the less densely packed earth associated with the foundation cut. It seems, then, that the builders of the South Basilica made an effort to seal the foundations against water run-off from the roof or surfaces while counteracting the seepage of ground water. A similar plaster rim, its distinctive aggregate matching that of the apse rim, ran along the eastern half of the exterior south aisle wall, marking it as part of the first phase of construction at the church. The later construction of the south portico, with its re-crystallised limestone floor and the insertion of the large rubble drain course to the south of the basilica, discussed below, may have rendered the plaster lip unnecessary.

The south side of the basilica saw a more substantial effort to manage the flow of water downslope in the area. The continued presence of a paved road to the upslope, south side of the church and the probable existence of an open courtyard immediately to the south of the building would have exposed the southern foundation wall and the piers of the south portico to the corrosive effects of water run-off. In an effort to counter the risk of water destabilising the south foundations of the church, the builders designed the courtyard to act as a massive drain. Beneath a level of limey, packed earth, which probably represented the ground surface of the courtyard, a loose level of rubble which in some places exceeded a metre in depth may have functioned as a massive French drain designed to slow the flow of water moving south to the basilica and to prevent it from pooling against the south wall of the church or running directly down the soft foundation cuts of the walls. A coin found in packing under a floor that appears to run up onto the piers of the south portico coincides with the date of the ceramics to suggest a $7^{\text {th }}$-century date for the floor.

The rubble layer is most likely contemporary with the second phase of the basilica and extends almost to the depth of the basilica foundation. Later burials have probably disturbed the integrity of the limey, packed floor, but there is no pottery in the packing that is later than the $7^{\text {th }}$ century with CRS9 being the latest present. The massive levelling course of rubble below the floor packing was, in turn, cut by the foundation of the piers of the south portico. In levels associated with the foundations of the portico the latest material dates to between 600 and 700 and includes well-documented CRS Form 10. Below the level of the foundations, however, the material is slightly earlier, in general perhaps representing a late $6^{\text {th }}$ - to early $7^{\text {th }}$-century date. This rubble level appears to 
sit immediately atop early Roman deposits dating from the $1^{\text {st }}$ century $\mathrm{BC}$ to the $1^{\text {st }}$ century AD and an earlier level of Hellenistic date. The diverse assemblage of fine wares, kitchen wares, and transport and utilities wares present in the massive rubble levelling course indicates that it was not only the product of a well-provisioned and connected community, but that the rubble course was at least partially associated with discard from other locations in the community. The large-scale levelling of the site must have been a major operation and testifies to the importance of this building project within the larger community of late antique Arsinoe.

\section{The South Basilica in a Regional Context}

Connections can be detected between the South Basilica and other churches on the island and perhaps beyond. Networks of transportation and trade connected coastal sites such as Arsinoe with larger centres, and it is not difficult to imagine itinerant guilds of builders, masons and craftsmen communicating by following coastal sea routes throughout the region. ${ }^{14}$ Although our basilica was not as large and luxurious as others on the island, it must have been the product of the same workshops. This is of course visible in decorative trends (mosaic, sculpture, champlevé panels) as well as architectural form. But it must also be traceable in smaller, less obvious ways such as building methods, materials and renovations. Similarities in planning, for example overall squarish proportions or the choice of polygonal apses (or combination of circular and polygonal apses as in the South Basilica) forge connections between buildings and sites. The separation of eastern apse foundations from the main body of the church, as found at the South Basilica and throughout the island, may signal a common practice among a particular group of builders. This was perhaps an attempt to alleviate structural problems that could result from seismic activity. Likewise, structural renovations (addition of pier buttresses, gradual thickening of walls, the shift to vaulting) continue to be a crucial element in the medieval architectural history of Cyprus. The Polis excavations in the South Basilica contribute to ongoing debates by showing that some communities, at least, were refurbishing their churches less than a century after their initial construction, and perhaps much less than this. Reasons for renovating may be many and diverse but need not be limited to dramatic historical events or natural disasters. The community in Arsinoe was likely not immune to the influence of changes in architectural style or fashion.

On Cyprus, the site of Amathous proves to be a particularly compelling case for ascertaining connections with Arsinoe: The Acropolis Basilica there recalls the South Basilica in terms of planning, proportions and overall size. Its south portico, connecting to the narthex by means of a southern annex, is markedly similar as is the portico's curtain wall made up of elegant arched openings giving on to an open courtyard. ${ }^{15}$ Like the South Basilica, an elongated annex was situated east of the portico there. The control and movement of water in the surrounding areas was likewise an important consideration in

14. Roueché 2000; Leonard 2005.

15. Pralong 1994. 
its design. Comparisons with Amathous have already been detected in the North Basilica at Arsinoe, not only in its architecture but also in the nature and date of finds from the two sites. ${ }^{16}$ It seems likely that places on opposite sides of the island may well have hosted the same workmen even as they received goods from the same production centres via sea lanes that remained busy in the eastern Mediterranean before the $7^{\text {th }}$-century incursions of the Arabs. Meanwhile the Asia Minor coast, less than 50 miles north of the Chrysochou Bay and visible on clear days, may likewise prove to be fertile ground for discovering comparanda in the future. Cities such as Anemurium, for example, with its multiple midsized churches, may provide opportunities to investigate possible influences. ${ }^{17}$ As already mentioned, connections to this area have been firmly established in Cypriot ceramics of the period, with direct lines extending from the island, and Arsinoe in particular, to major cities on or near the coastal regions. Arsinoe's position on an important northern sea route linking Asia Minor and the Levant with the Aegean must have ensured not only its livelihood but also artistic and cultural connections with its surrounding neighbours.

Finally, the South Basilica, with its original nucleus of nave and side aisles, allows us to understand something of the piecemeal progress of construction in Late Antiquity. At Arsinoe, priorities of the building project are clear: The central naos could stand alone, with additional satellite rooms (narthex and south portico) delayed to a later phase. Available finances or the availability of craftsmen, or both, were likely responsible. On the other hand, concerns for waterproofing and drainage loomed large and demanded immediate attention. All this goes some way toward apprehending attitudes in Late Antiquity toward building processes, not to mention a community's concern for and care of its most important buildings. The findings of the Princeton excavation will enable us to focus not only on more obvious, stylistic trends apparent in the South Basilica, but on the minutiae of the building process as it evolved over time.

University of North Dakota (W. C.) / Indiana University of Pennsylvania (R.S. M.) / Boston University (B.R. O.) / The Richard Stockton University of New Jersey (A. P.)

\section{Acknowledgements}

We would like to thank the Department of Antiquities of Cyprus and William A.P. Childs, Director of the Princeton University expedition to Polis, for permission and access to materials from area E.F2. The Department of Art and Archaeology at Princeton University and the Vice President of Research at the University of North Dakota funded our seasons at the site, with additional support from Dumbarton Oaks in the form of a project grant. Our excavation foreman, Alexandros Koupparis, kindly offered last-minute help. The ceramic profiles are the work of Brandon R. Olson; the master plans of the site were produced by our excavation architects over the years, especially Nora Laos, Charles Nicklies, Kelly Des Roches, Krista Ziemba and Elise Chassé.

16. Najbjerg, Nicklies, Papalexandrou 2002.

17. Russell 2002. 


\section{BIBLIOGRAPHY}

Baker (B.), Papalexandrou (A.), 2012, “A Bioarchaeological Perspective on Burials and Basilicas of Medieval Polis, Cyprus", in M.A. Perry (ed.), Bioarchaeology and Behavior. The People of the Ancient Near East, Gainesville, FL, p. 80-114.

Catling (H.W.), 1972, "An Early Byzantine Pottery Factory at Dhiorios in Cyprus", Levant 4, p. 1-82.

Childs (W.A.P.), Smith (J.), Padgett (M.) eds, 2012, City of Gold. The Archaeology of Polis Chrysochous, Cyprus, Princeton.

ĆurČIć (S.), 1999, "Byzantine Architecture on Cyprus: An Introduction to the Problem of the Genesis of a Regional Style", in N. Ševčenko, C. Moss (eds), Medieval Cyprus: Studies in Art, Architecture and History in Memory of Doula Mouriki, Princeton, p. 71-80.

Hayes (J.), 1992, Excavations at Saraçhane in Istanbul: The Pottery, Princeton.

Leonard (J.R.), 2005, "Roman Cyprus: Harbors, Hinterlands, and 'Hidden Powers' ", unpublished Ph.D. thesis, The State University of New York at Buffalo.

Megaw (A.H.S.), Hawkins (E.J.W.), 1977, The Church of the Panagia Kanakariá at Lythrankomi in Cyprus, Washington, DC.

Meyza (H.), 2007, Cypriot Red Slip Ware: Studies on a Late Roman Levantine Fine Ware (Nea Paphos V), Warsaw.

NajbJerg (T.), 2012, "The City of Arsinoe in the Hellenistic and Roman Periods", in Childs, Smith, Padgett 2012, p. 232-248.

NajbJerg (T.), Nicklies (C.), Papalexandrou (A.), 2002, "Princeton University Excavations at Polis/Arsinoe: Preliminary Report on the Roman and Medieval Levels", RDAC, p. 139-154.
Papalexandrou (A.), 2012, "Polis/Arsinoë in Late Antiquity: A Cypriot Town and its Sacred Sites", in M.J. Johnson, R. Ousterhout, A. Papalexandrou (eds), Approaches to Byzantine Architecture and its Decoration. Studies in Honor of Slobodan Curčić, Farnham \& Burlington VT, p. 27-46.

Papalexandrou (A.), Caraher (W.), 2012, "Arsinoe in Late Antiquity and the Middle Ages", in Childs, Smith, Padgett 2012, p. 267-284.

Pralong (A.), 1994, "La Basilique de l'Acropole d'Amathonte", Rivista di Archeologia Cristiana 70, no. 1-2, p. 411-455.

Rautman (M.), 2003, A Cypriot Village of Late Antiquity. Kalavassos-Kopetra in the Vasilikos Valley (Journal of Roman Archaeology, Supplementary Series 52), Portsmouth, R.I.

Roueché (C.), 2000, "Asia Minor and Cyprus", in A. Cameron, B. Ward-Perkins, M. Whitby (eds), Late Antiquity: Empire and Successors, AD 425-600 (Cambridge Ancient History vol. 14), New York, p. 570-587.

Russel (J.), 2002, “Anemourion”, in A.E. Laiou (ed), The Economic History of Byzantium. From the Seventh through the Fifteenth Century, Dumbarton Oaks, p. 221-228.

Stewart (C.), 2010, "The First Vaulted Churches in Cyprus", Journal of the Society of Architectural Historians 69, no. 2, p. 162-189.

Williams (C.), 1977, "A Byzantine WellDeposit from Anemurium (Rough Cilicia)", Anatolian Studies 27, p. 175-190.

Williams (C.), 1992, Anemurium. The Roman and early Byzantine pottery, Toronto. 